\title{
Microbial life in pelagic sediments: the impact of environmental parameters on enzymatic degradation of organic material
}

\author{
Lutz-Arend Meyer-Reil, Marion Köster \\ Institut für Meereskunde an der Universität Kiel, Abteilung Marine Mikrobiologie, Düsternbrooker Weg 20, W-2300 Kiel 1, \\ Germany
}

\begin{abstract}
The impact of environmental parameters, such as salinity, temperature, pressure, and nutrients, on microbial activity was investigated in pelagic sediments of the Norwegian-Greenland Sea (water depth between 1400 and $2000 \mathrm{~m}$ ). As a general characteristic of benthic microbial activity, the enzymatic degradation of organic material, which represents the initial and rate-limiting step in carbon oxidation, was measured. For the enzymatic analysis, fluoresceindiacetate was used, a fluorogenic model substrate which is hydrolyzed non-specifically by hydrolytic enzymes. The substrate was added at saturation level, and potential enzymatic activity rates were derived from the slope of the linear part of time-dependent activity curves. From the investigations it can be concluded that the pool of hydrolytic enzymes in the pelagic sediments was not specifically adapted to ambient parameters such as salinity, temperature, and pressure. There was no indication of a psychrophilic and/or barophilic response. Enzymatic degradation of organic material was more regulated by the supply of organic material than by cold temperature and elevated pressure. Boiled detritus added to sediment cores incubated under in situ temperature on board ship caused an immediate stimulation of hydrolytic enzymes. The location of microorganisms in the sediment and the unique characteristics of microbial metabolism must both be considered as possible strategies for using the incoming organic material effectively and for surviving the long periods of nutrient deficiency in pelagic sediments
\end{abstract}

\section{INTRODUCTION}

Compared to that in shallow-water sediments, microbial life in pelagic sediments is still under-investigated. This undoubtedly reflects the considerable logistical effort that is necessary to sample sediments in deeper waters. Furthermore, until recently the deeper regions of the seafloor attracted only limited scientific interest. Pelagic (deep-sea) sediments were understood as potentially hostile environments where low temperature, elevated pressure and low nutrient levels restricted microbial metabolic activity. During the last decade, however, the study of deeper waters (including sediments) has gained increasing attention, and extensive joint research programs have been established to study the parameters influencing the flow of organic material and microbial activity in the deep sea. Based on these studies, the conventional view of the seafloor as a nutrient-poor environment that continuously receives a low input of organic matter of low nutritional value (Jannasch 1979) had to be modified. It became quite obvious that pelagic sediments are supplied with pulses of relatively fresh organic material via sedimentation from euphotic waters. Quantity and quality of the sedimented material were found to be subject to pronounced seasonal variations, which were reflected in the metabolic activity of the microbial assemblages (Lochte \& Turley 1988, Graf 1989). Most of the organic matter oxidation occurred at the sediment surface and involved oxygen or possibly secondary oxidants (Bender \& Heggie 1984). The metabolic rates measured were much more rapid than had been previously thought, considering the low temperature and elevated pressure (Deming 1986, Reimers \& Smith 1986, Cole et al. 1987, Graf 1989). The regulation of microbial activity by temperature and pressure in the deep sea is still a matter of investigation. Although obligate barophilic bacteria have been cultured from deep-sea samples (cf. literature cited by Chastain \& Yayanos 1991, Turley et al. 1988), the question still remains as to whether the degradation of organic material in the deep sea is governed by barophilic (and psychrophilic) responses. 
In the present study, the impact of environmental parameters, such as salinity, temperature, pressure, and nutrients, on microbial activity in pelagic sediments of the Norwegian-Greenland Sea was investigated. The analyses were based on the measurement of the enzymatic (hydrolytic) degradation of organic material as a general determinant of benthic microbial activity. To our knowledge, this is the first detailed report on the measurement of enzyme activity in pelagic sediments.

\section{METHODS}

Sediment samples. The experiments described below were carried out using sediments collected with a multiple corer equipped with plastic tubes $110 \mathrm{~cm}$ diameter, $60 \mathrm{~cm}$ length), during expeditions of the RV 'Meteor' in the Norwegian-Greenland Sea in 1988 and 1990 (cruises M 7/4-5 and M 13/1 respectively). We sampled at the following locations and dates: Stn 468 , 19 August 1988, water depth $1243 \mathrm{~m}, 67^{\circ} 44.1^{\prime} \mathrm{N}$, $5^{\circ} 55.0^{\prime} \mathrm{E}_{\mathrm{i}} \operatorname{Stn} 576,18$ September $1988,1745 \mathrm{~m}$, $70^{\circ} 20.1^{\prime} \mathrm{N}, 10^{\circ} 37.8^{\prime} \mathrm{E} ; \mathrm{Stn} 383,10$ July $1990,1423 \mathrm{~m}$, $67^{\circ} 39.0^{\prime} \mathrm{N}, 5^{\circ} 47.0^{\prime} \mathrm{E}$; Stn 499, 26 July 1990, $2003 \mathrm{~m}$, $75^{\circ} 10.0^{\prime} \mathrm{N}, 12^{\circ} 39.8^{\prime} \mathrm{E}_{;} \operatorname{Stn} 533,30$ August 1990, $1243 \mathrm{~m}, \quad 67^{\circ} 44.1^{\prime} \mathrm{N}, \quad 5^{\circ} 55.6^{\prime} \mathrm{E}$. Immediately after retrieval sediment cores were processed for the various experiments in a constant-temperature room operated at close to in situ temperature $\left(0\right.$ to $\left.2^{\circ} \mathrm{C}\right)$. For standardization experiments as well as for studies on the influence of salinity, temperature, and pressure on enzymatic activity, sediments were dissected and individual strata used for the corresponding experiments. Nutrient enrichment experiments were carried out with intact sediment cores.

Enzymatic activity. To analyse the activity of hydrolytic enzymes, $500 \mu 1$ aliquots of dissected and suspended sediment (1:5 in bottom water from the corresponding station, sterilized through $0.2 \mu \mathrm{m}$ filters) were pipetted into centrifuge tubes. Previous experiments had indicated that the concentration of free dissolved enzymes in filter-sterilized bottom water was below the detection limit. The enzymatic reaction was started by adding $10 \mu \mathrm{l}$ of fluoresceindiacetate (FDA, $4.8 \mathrm{mM}$ solution in acetone; Serva Chemical Co.). The enzyme assays were run in time-course experiments (generally 5 incubation periods; duplicate samples). Following incubation the samples were centrifuged (6000 rpm, 15 min; $0^{\circ} \mathrm{C}$ ), and the supernatants were siphoned off. Previous experiments had shown that after separation of the particles, the fluorescence in the supernatant did not change. This means that the measurable portion of the enzymatic response was bound to particles and associated cells. After acclimatization to room temperature $\left(\mathrm{ca} 20^{\circ} \mathrm{C}\right.$ ), the release of the fluorescent dye in the supernatant was read in a spectrofluorometer (Kontron SFM 25) at $470 \mathrm{~nm}$ excitation and $510 \mathrm{~nm}$ emission. As standards, 0.1 to 1 uM dilutions of fluorescein (Serva Chemical Co.) were freshly prepared with filtersterilized bottom water from a $1 \mathrm{mM}$ stock solution in acetone. By plotting the release of fluorescein versus incubation time, enzymatic activity curves were obtained from which hydrolysis rates were calculated by linear regression. Correlation coefficients were significant at least at the $95 \%$ confidence level. Sediment suspensions boiled for $30 \mathrm{~min}$ and treated as described above served as controls. Results from standardization experiments as well as from investigations on the influence of pressure on hydrolytic activity were reported as original data in terms of relative fluorescence units, to illustrate in detail the enzymatic response over time. Results from experiments on the influence of salinity, temperature, and nutrients on enzymatic activity were recorded as hydrolysis rates ( $\mathrm{nmol}$ fluorescein released $500 \mathrm{\mu l}^{-1}$ sediment suspension $\mathrm{h}^{-1}$ ) based on a linear regression of the individual data.

Standardization. To investigate the dependence of hydrolytic activity upon substrate concentration and incubation time, standardization experiments were performed. Surface sediments $(0-2 \mathrm{~cm}$ stratum) from Stn 576 were diluted 1:5 with filter-sterilized bottom water, and $500 \mu$ aliquots were pipetted into centrifuge tubes. FDA was added to duplicate samples in various concentrations $(0.24,0.48,2.4,4.8,9.6$, and $19.2 \mathrm{mM})$, and incubated for $0.5,1,1.5,2,2.5$, and $3 \mathrm{~h}$. Following incubation, samples were treated as described above. From the linear part of the activity response, the substrate saturation curve was obtained by plotting substrate concentration versus hydrolysis rate.

Salinity experiments. Sediments $(0-1 \mathrm{~cm}$ and $6-7 \mathrm{~cm}$ strata) from Stn 533 were diluted 1:5 with water of different salinities (ca 36, 27, 18, 9 and $0 \%$ ), which were obtained by diluting filter-sterilized bottom water with tap water. Aliquots $(500 \mu \mathrm{l})$ of the samples were pipetted into centrifuge tubes, and an enzyme assay was performed as described above.

Temperature experiments. Surface sediments $(0-2 \mathrm{~cm}$ stratum) from $\mathrm{Stn} 383$ were prepared for the enzyme assay as described above. The enzyme assay was run at different temperatures ranging from 0 to $46.5^{\circ} \mathrm{C}$.

Pressure experiments. Sediment cores from Stn 499 were dissected and diluted as described above. Aliquots (2 ml) of the sediment suspensions (diluted $1: 5$ ) from the $0-1 \mathrm{~cm}$ and $6-7 \mathrm{~cm}$ strata (generally 4 parallels) were pipetted into syringes, and FDA $(40 \mu \mathrm{l}$ of a $4.8 \mathrm{mM}$ solution) was added. After the air was carefully removed, the needle of the syringes was sealed by a rubber stopper, and the samples were incubated in pressure vessels at in situ temperature under atmos- 
pheric and close to in situ pressure (200 atm). Following incubation the enzymatic response was measured as described above

Nutrient enrichment experiments. Intact sediment cores from Stn 468 were incubated on board ship at in situ temperature $\left(1^{\circ} \mathrm{C}\right)$. After $4 \mathrm{~d}$ of acclimatization, one set of the cores was enriched with detrital material. and the remaining untreated cores served as controls. The detrital material was sampled from a water depth of $140 \mathrm{~m}$ by concentration through a $20 \mu \mathrm{m}$ plankton net. After being suspended in surface water, the material was boiled for $30 \mathrm{~min}$, homogenized using a pistil, and washed twice by centrifugation. Aliquots ( $5 \mathrm{ml}$ ) of the boiled detritus (equivalent to $200 \mathrm{mg}$ dry wt of material and $8.7 \mathrm{mg}$ of carbon, respectively) were carefully added with a pipette to the water overlying the sediment, thus distributing the material on the sediment surface. At regular intervals, 2 to 4 of the treated and untreated cores were removed and dissected in 0.5 to $1 \mathrm{~cm}$ strata down to a depth of $8 \mathrm{~cm}$. After combining the corresponding strata and diluting them in filter-sterilized bottom water, sediment suspensions were analysed for enzymatic activity as described above. Although the material added to the sediment cores did not represent natural detritus, we believe it was the closest possible simulation of natural, sedimenting detritus that could be obtained experimentally.

\section{RESULTS}

\section{Standardization of the enzyme assay}

For measurement of enzyme activity rates, different concentrations of FDA were applied, the hydrolysis of which was followed in time-course experiments. As can be seen from Fig. 1, the activity response was linear for at least 2 h over a broad range of substrate concentrations. In more than $90 \%$ of the sediments investigated, enzyme activity increased linearly with prolonged incubation. However, in the surface strata of some sediments induction phenomena were observed, leading to increased rates of enzyme response over time. From the enzyme activity response measured at different substrate concentrations, the substrate saturation curve could be extrapolated. Based on this curve, it could be concluded that concentrations of FDA around $5 \mathrm{mM}$ are sufficient to saturate the enzymes (Fig. 1). Corresponding standardization experiments performed with a variety of different sediments from the Norwegian-Greenland Sea confirmed the above results. In boiled sediments enzymatic activity was completely inhibited whereas treatment with chemicals, such as acetone, mercuric chloride, glutaraldehyde or formal-

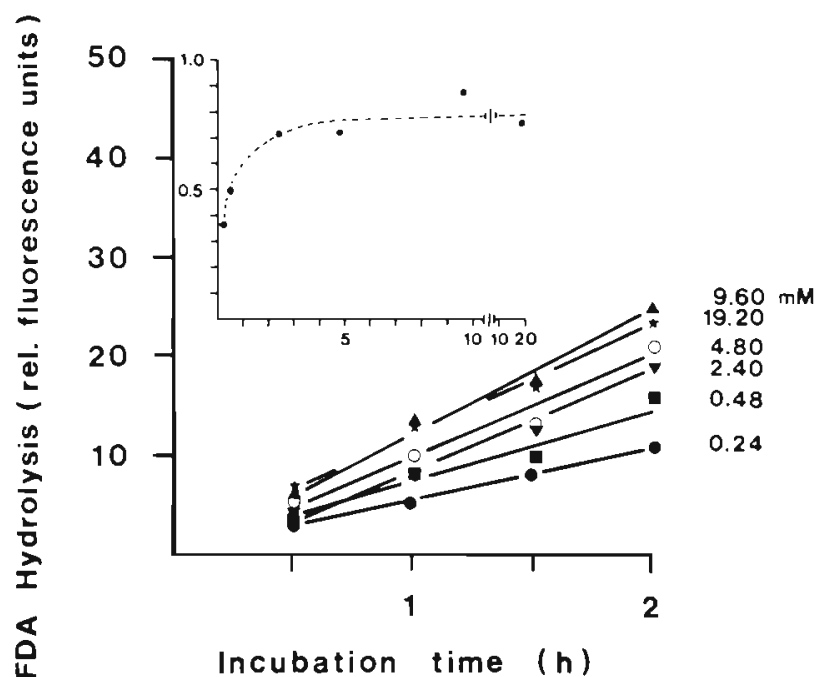

Fig. 1. Hydrolytic activity vs substrate concentration and incubation time in sediment suspensions from Stn $576(0-2 \mathrm{~cm}$ stratum). In the inset the substrate saturation curve is illustrated by plotting concentration of fluoresceindiacetate (mM, horizontal axis) added to the sediment suspensions against hydrolysis rates (nmol fluorescein $500 \mathrm{\mu l}^{-1} \mathrm{~h}^{-1}$ )

dehyde, only partly restricted hydrolytic activity (cf. Meyer-Reil 1990). Since enzymatic activity was extrapolated from the slope of the time-dependent activity curves, the problem of proper controls was of minor importance. In none of the sediments investigated from the Norwegian-Greenland Sea did adsorption of the dye (fluorescein) released account for more than $5 \%$ of the fluorescence measured in the samples, as evidenced by recovery of fluorescein after addition to sediment suspensions

\section{Enzyme activity dependent upon salinity}

Hydrolytic enzymes were active over a broad range of salinities (cf. Table 1). While similar activity rates were measured in full-strength and slightly diluted seawater (salinity range between ca 27 and $36 \%$ ), the enzymatic response increased with decreasing salinity. Different sediment horizons $(0-1$ and $6-7 \mathrm{~cm})$ reacted similarly to variations in salinity. Corresponding results were obtained for different sediments from the Norwegian-Greenland Sea.

\section{Enzyme activity depending upon temperature}

Hydrolytic activity of enzymes in sediments of the Norwegian-Greenland Sea considerably increased with increasing temperature (Fig. 2). Optimum enzy- 
Table 1. Hydrolytic activity rates (nmol fluorescein $500 \mathrm{ul}^{-1} \mathrm{~h}^{-1}$ ) relative to salinity in sediment suspensions from Stm 533 . See text for details

\begin{tabular}{|c|c|c|c|c|c|}
\hline \multirow[t]{2}{*}{ Sediment horizon } & \multirow[t]{2}{*}{ Freshwater } & \multicolumn{3}{|c|}{ Seawater diluted with freshwater } & \multirow[t]{2}{*}{ Seawater } \\
\hline & & $1: 4$ & $1: 2$ & $3: 4$ & \\
\hline $0-1 \mathrm{~cm}$ & 3.11 & 2.42 & 1.95 & 1.46 & 1.48 \\
\hline $6-7 \mathrm{~cm}$ & 2.47 & 1.54 & 1.26 & 0.96 & 1.07 \\
\hline
\end{tabular}

matic activity was recorded around $46^{\circ} \mathrm{C}$. Above this temperature, the enzymatic response decreased, which may have been due to denaturation of protein. This experiment, which was repeated for different sediments of the Norwegian-Greenland Sea, indicated no stimulation of enzyme activity in the low temperature range. Parallel investigations revealed that thermal degradation of FDA was insignificant in the temperature range investigated.

\section{Enzyme activity dependent upon pressure}

For investigations on the influence of pressure on hydrolytic activity in sediments of the NorwegianGreenland Sea, a station at $2000 \mathrm{~m}$ water depth was chosen. The experiments included 2 different strata: $0-1$ and 6-7 cm. From the enzyme activity curves measured, there was no indication of a pronounced stimulation of hydrolytic activity at in situ, as compared to atmospheric, pressure (Fig. 3). While at the surface the enzymatic activity rates seemed to increase with prolonged incubation, the $6-7 \mathrm{~cm}$ stratum revealed a

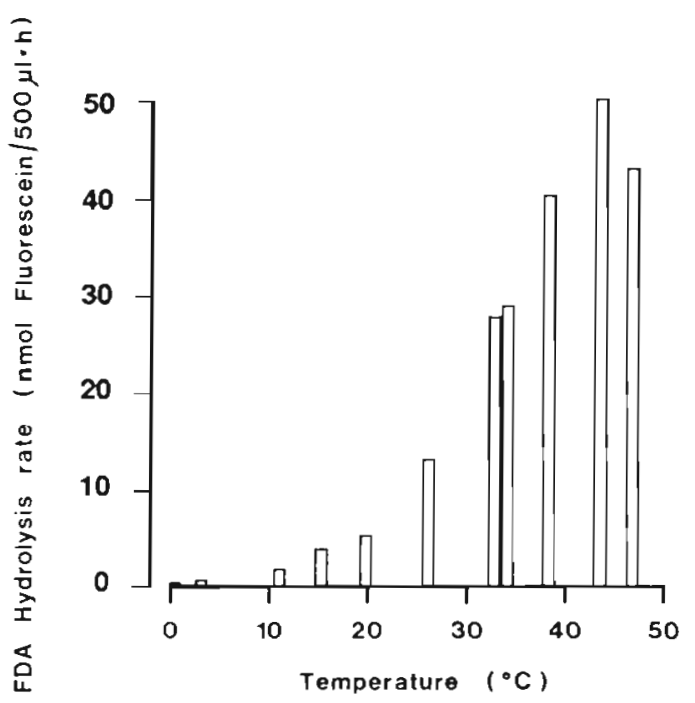

Fig. 2. Hydrolytic activity vs temperature in sediment suspensions from $\operatorname{Stn} 383(0-2 \mathrm{~cm}$ stratum)

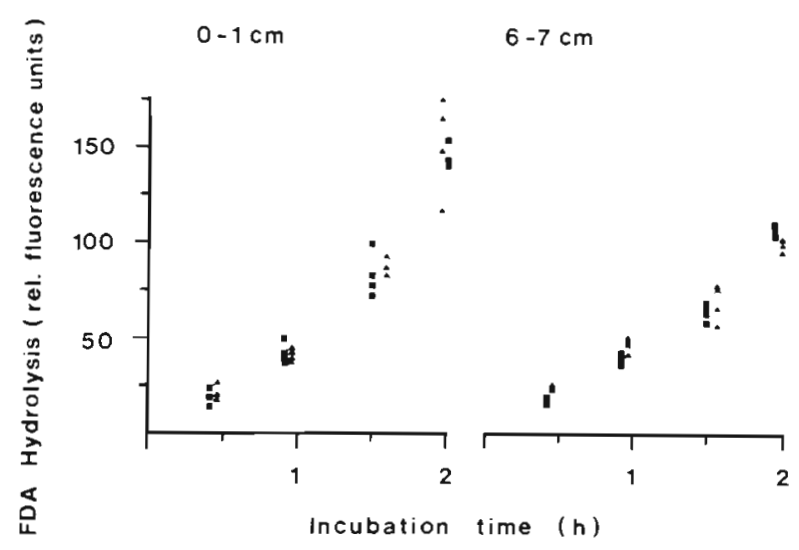

Fig. 3. Hydrolytic activity vs pressure (-1 atm, $200 \mathrm{~atm})$ in sediment suspensions from $S t n 499$. In the $0-1 \mathrm{~cm}$ stratum, the calibration factor was higher by a factor of 10 compared to the $6-7 \mathrm{~cm}$ stratum

linear response. Additional experiments were carried out with sediments from a location at ca $3000 \mathrm{~m}$ water depth. Surface sediments were analysed for hydrolytic activity at in situ temperature $\left(0^{\circ} \mathrm{C}\right)$ and $37^{\circ} \mathrm{C}$ under in situ and atmospheric pressure (data not shown). Again there was no indication of a pronounced stimulation of enzyme activity by in situ pressure conditions at both temperatures (ratio of enzyme activity in sediments incubated under in situ pressure to that of sediments under atmospheric pressure $=1.2$ )

\section{Enzyme activity dependent upon nutrients}

To investigate the influence of nutrients on microbial communities in pelagic sediments, enrichment experiments were carried out on board ship. Intact sediment cores were incubated at in situ temperature with and without the addition of boiled detritus, and analysed for various parameters related to benthic metabolism (Köster et al. 1991b). For this experiment only the impact of nutrients on hydrolytic activity is discussed here. As can be seen from following the hydrolysis of FDA in sediment profiles (Fig. 4), the availability of organic material led to an immediate stimulation of microbial enzymatic 


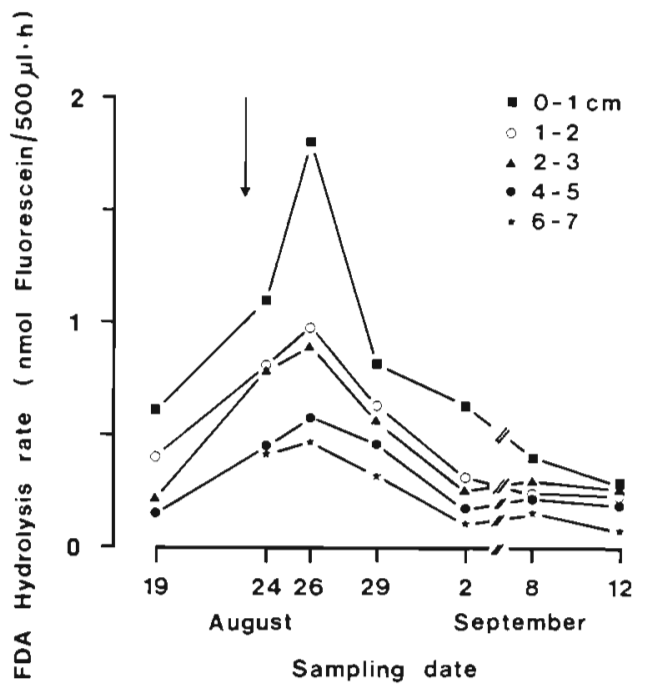

Fig. 4. Time-course development of hydrolytic activity dependent upon nutrients in sediments from $\operatorname{Stn} 468$. Intact sediment cores were incubated on board ship at in situ temperature, dissected, and the individual strata analysed for hydrolytic activity. Arrow indicates the date of nutrient addition

activity. As early as $1 \mathrm{~d}$ after nutrient addition, hydrolytic activity was enhanced by a factor of almost 2 (compared to the enzymatic activity measured in the original sediment). Maximum enzyme activity occurred $3 \mathrm{~d}$ after nutrient enrichment. Stimulation was initiated at the sediment surface and spread out relatively quickly into deeper strata. With prolonged incubation hydrolytic activity decreased, and $10 \mathrm{~d}$ after nutrient addition, the enzyme levels originally measured were reached. During the initial $2 \mathrm{~d}$ of incubation on board ship, an increase in enzyme activity was observed in the sediment cores. However, this 'incubation' effect had already worn off by the time the detritus was added.

\section{DISCUSSION}

Our investigation of the impact of physico-chemical and chemical parameters on microorganisms in pelagic sediments was based on measurements of the enzymatic degradation of organic material, a general characteristic of microbial metabolism. Since the overwhelming proportion of organic carbon entering pelagic sediments is particulate or higher-molecular-weight material, its enzymatic degradation represents the initial and rate-limiting step in organic carbon oxidation (Billen 1982, Meyer-Reil 1990).

FDA, used in this study for enzymatic activity measurements, is a fluorogenic model substrate that is hydrolyzed non-specifically by hydrolytic enzymes (e.g. phosphatases, lipases, carbohydrate- and proteindecomposing enzymes; cf. Meyer-Reil 1991 and litera- ture cited therein). The hydrolytic attack results in the release of fluorescein, which is highly fluorescent, thus allowing very sensitive activity determinations.

The location of enzymes acting in sediments (bound to cell walls and/or associated with particles) as well as the origin of the enzymes (indigenous and/or derived from sedimenting material) remains unclear (MeyerReil 1991). The contribution of intracellular hydrolysis to the (extracellular) activity rates measured is still a matter of discussion (Lundgren 1981, Chrzanowski et al. 1984, Meyer-Reil 1991). FDA has been used to determine microbial biomass and activity in a variety of environments. By means of FDA, Swisher \& Carroll (1980) estimated microbial biomass on the surface of coniferous needles; Schnürer \& Rosswall (1982) determined total microbial activity in soil and litter; and Köster et al. (1991a) and Meyer-Reil \& Köster (1991) examined the pool of hydrolytic enzymes in pelagic sediments of the Norwegian-Greenland Sea. These investigations confirmed that FDA hydrolysis provides a very sensitive enzyme assay for rapidly assessing hydrolytic potential, even in sediments with very low enzymatic response levels (see below).

In the present study, sediment slurries were prepared, and FDA was applied at the saturation level. Because of this, the hydrolysis rates measured describe potential activities. However, the rates reflected the pool of naturally occurring enzymes, which represents the result of previous variations in concentration and composition of natural substrates (Meyer-Reil 1991). In standardization experiments different concentrations of FDA were used; these experiments generally confirmed that the enzymatic response was linear over time, thus justifying extrapolation of activity rates (substrate degradation per volume of sediment per time). Since FDA was applied at the saturation level, the kinetics approached zero order, the enzyme activity being no longer dependent upon substrate concentration. Based on the standardization experiments, basic requirements for the proper measurement of activity rates could be fulfilled (Fig. 1)

Investigation of the impact of environmental parameters on enzymatic activity revealed general characteristics of the hydrolytic enzyme pool in pelagic sediments of the Norwegian-Greenland Sea. Hydrolytic activity increased with decreasing salinity, which might have been due to osmotic effects (lysis of cells, liberation of enzymes from particles), thus enhancing the access of substrate to the enzymes (Table 1). Hydrolytic activity considerably increased with increasing temperature (Fig. 2). The optimum was observed around $45^{\circ} \mathrm{C}$, which is in general agreement with the optimum temperature reported for $\beta$-glucosidase and proteolytic enzymes in intertidal sediments (King 1986, Mayer 1989). There was no indication of a psychrophilic 
response in the low temperature range. Hydrolytic activity measured at atmospheric and in situ pressure (200 atm) displayed no pronounced difference (Fig. 3). This held true for surface and subsurface sediment horizons as well as for different temperatures $(0$ and $37^{\circ} \mathrm{C}$ ). Therefore the pool of hydrolytic enzymes investigated must be characterized as barotolerant rather than barophilic.

However, the supply of decomposable organic material caused considerable stimulation of enzyme activity. Boiled detritus added to intact sediment cores incubated at in situ temperature on board ship caused immediate induction of hydrolytic activity As could be expected from the enrichment of organic carbon at the sediment surface, enhanced activity began at the surface and then extended relatively quickly into deeper sediment strata (Fig. 4). Additional analyses (data not shown $;$ cf. Köster et al. 1991b) revealed that there was a definite time sequence in the stimulation of microbial metabolic processes (cf. Kirchman et al. 1986). Following enzymatic degradation of organic material (Fig. 4), the hydrolysis products were taken up by the microorganisms, and subsequently microbial biomass production (as evidenced by the incorporation of tritiated leucine) increased. The relatively low incorporation of hydrolysis products into microbial biomass seemed to indicate that at least during the early stages of decomposition, a high percentage of the organic carbon taken up by the microorganisms was respired. The data presented in this paper confirm the importance of enzymatic hydrolysis as a key step in degrading organic material and initiating subsequent microbial metabolism of the hydrolysis products.

Based on the experiments, it can be concluded that the pool of hydrolytic enzymes in sediments of the Norwegian-Greenland Sea was not specifically adapted to ambient parameters such as temperature and pressure. Because both parameters can be regarded as constant over geological time periods, one would expect that the pool is dominated by psychrophilic and barophilic enzymes, respectively. Instead, the majority of enzymes prevalent must be characterized as tolerant against temperature and pressure. These observations seem to conflict somewhat with the literature, from which one may obtain the impression that the barophilic response in particular is characteristic of microbial life in deep-sea environments (e.g. Deming 1985, Deming \& Colwell 1985, Rowe \& Deming 1985, Chastain \& Yayanos 1991). However, only a minority of the bacteria cultured from the deep sea displayed a true (obligate) barophilic response (cf. literature cited by Chastain \& Yayanos 1991), and field studies measuring microbial metabolic activities (uptake of organic substrates, growth) very rarely show a pronounced positive influence of pressure. These observations (together with the data presented) may be taken as an indication that barophily is not as widespread in the deep-sea environment as was previously thought. However, the question of pressure regulation of microbial activity in the deep sea must be approached somewhat differently, taking into account the nutrient requirements of deep-sea bacteria (Deming \& Baross 1992).

One may argue that the pelagic sediments investigated in this study (water depth around $2000 \mathrm{~m}$ ) do not represent 'deep-sea' conditions. The question then arises, 'How deep is the deep sea?' To our knowledge, there is (and will be) no unequivocal definition of the deep sea (cf. Deming 1986, Austin 1988). However based on the distance from terrestrial influence and the supply of organic material, the sediments investigated in the Norwegian-Greenland Sea can be regarded as situated in a deep-sea environment. There is no reason why barophilic microbial activity (if at all dominant) should not be found there, especially since the initial enzymatic breakdown of organic material, and not resultant growth, was measured as the determinant of microbial activity in this study (cf. remarks of Deming 1985 on the suitability of microbial growth measurements in the deep sea).

Generally, it has to be considered that data on the impact of pressure on deep sea microorganisms mostly rely on samples that were depressurized during ascent to the surface and repressurized again. Possible deleterious effects of decompression on the microorganisms cannot be excluded. However, it is difficult to conclude that, so long as low temperatures were maintained throughout retrieval and processing of samples, all of the barophilic microorganisms (including their enzymes) would have been irreversibly damaged. Nevertheless, much more work using pressure- (and temperature-) retaining samplers is needed to answer unequivocally the question of the impact of pressure on deep-sea microorganisms.

The experiments indicate that the supply of organic material is the dominant factor governing microbial decomposition processes in pelagic sediments. Enzymatic degradation of organic material was regulated more by the availability of decomposable organic carbon than by cold temperature and elevated pressure prevailing in pelagic (deep-sea) sediments. Since the nutrient supply undergoes pronounced variations in quantity and quality (e.g. Lochte \& Turley 1988, Graf 1989), deep-sea microorganisms must have developed strategies for both using incoming organic material effectively and withstanding (long) periods of nutrient deficiency In discussing such strategies, the location of microbial cells in the sediment as well as the special characteristics of microbial metabolism must be considered. Microorganisms floating free in the pore water, 
and particularly those trapped in the organic matrix, have only fortuitous access to sedimented particulates (Meyer-Reil 1990) In contrast, microorganisms associated with biogenic structures (burrows, tubes) or living on or in higher (motile) organisms have a much better chance of coming in contact with an energy source (cf. general discussion by Morita 1979). As shown by e.g. Aller \& Aller (1986) and Köster et al. (1991a), relict burrows of macrofauna in deep-sea sediments are sites of enhanced biological activity. This applies also to the gut of macrofaunal organisms (latter study), although the origin of the enzyme activity measured could not be unequivocally identified (i.e. whether microbial or macrofaunal). The data of Köster et al. (1991a) suggest that the main degradation processes in pelagic sediments of the Norwegian-Greenland Sea indeed occurred in association with biogenic structures and higher organisms.

The general features of microbial metabolism allow microorganisms to use incoming organic material effectively and to withstand long periods of nutrient deficiency. Microbial communities possess a broad spectrum of enzymes that make them extraordinarily versatile in their degradation potential with regard to a variety of organic materials. Enzymes of oligotrophic bacteria in particular are characterized by their high affinity (low $K_{\mathrm{m}}$ value) for the uptake of a variety of utilizable substrates, using transport systems with low substrate specificity (Morita 1982). Whether this applies to deep-sea microorganisms must be investigated as well. As demonstrated by the nutrient enrichment experiment (cf. Fig. 4), the cells were able to react very quickly with stimulation of enzyme production when decomposable organic material became available. The occurrence of a distinct time lag between enzyme and biomass production (cf. Köster et al. $1991 \mathrm{~b}$ ) indicated that the metabolic pathways of the microbial assemblages were unbalanced, due to a 'shift up' from a nutrient-poor to a relatively nutrient-rich metabolic status (Kirchman et al. 1986). As could be shown by biomass production measurements (using tritiated leucine; Köster et al. 1991b), less than 1\% of the carbon supplied was incorporated into microbial biomass. This means that (at least during the early stages of decomposition) only a minor part of the organic carbon was available for microbial decomposition processes, and/or a high proportion of the organic material was used for maintenance processes. Microbial biomass production as well as cell division may become more important during later stages of organic matter utilization. Corresponding observations were reported by Gooday (1988) and Gooday \& Lambshead (1989), who found a dramatic response by certain benthic Foraminifera to the deposition of phytodetritus in the deep sea.
During the long periods of nutrient deficiency in deep-sea sediments, bacteria may enter a survival state, in which the cells become inactive (dormant) while still retaining the ability to react if nutrient conditions become more favourable (Morita 1982). One of the most obvious manifestations of starved cells is shrinkage, which increases the ratio between cell surface and volume, thus enhancing the cells' ability to scavenge energy-yielding substrates from the environment. Epifluorescence microscopic analysis of the microbial assemblages in the sediment revealed that the size range of microorganisms rapidly decreased with increasing sediment depth. Whereas at the sediment surface a broad range of microorganism shapes and sizes was present, in strata below $5 \mathrm{~cm}$ depth ca $90 \%$ of the microbial community consisted of small cocci (diameter between 0.2 and $0.4 \mu \mathrm{m}$ ), which may have been resting cells in some kind of a survival state (Meyer-Reil \& Köster unpubl.). Investigations of a sediment profile (water depth around $3000 \mathrm{~m}$ ) from Antarctica revealed that even in the $11 \mathrm{~m}$ stratum, $10^{9}$ cells $\mathrm{g}^{-1}$ dry wt sediment (exclusively small cocci) were present. The question of the physiological state of these microorganisms is still unsolved. They may be starvation forms resting for periods beyond the temporal scale of ecological studies (Meyer-Reil 1984).

Our present knowledge on organic matter decomposition by microbial communities in pelagic sediments is quite limited, especially with respect to the microbial decomposition processes and interactions between organisms that are involved. Some of the most urgent questions remaining are: Where are the decomposition processes located? What proportion of sedimented organic material is available for microbial decomposition? Is there any modification of the more resistant organic material due to microbial activity? What is the contribution of microorganisms acting in different compartments of the sediment to organic matter decomposition? How do consortia of microorganisms interact in order to degrade organic material effectively? Are there differences in the modification (and deposition) of organic matter if the incoming particulates are reworked by benthic communities of different composition? To answer these and related questions will require further investigations on deepsea sediments.

Acknowledgements. The authors greatly appreciate the participation of P. Yager from the working group of Dr J. W. Deming, University of Washington, Seattle, on the 'Meteor' cruise in 1990. P. Yager carefully performed the preparations and incubations of samples for the pressure experiments. The authors are grateful to $M$. Enmcke-Kasch and $H$. Held for excellent technical assistance. This work was supported by the Deutsche Forschungsgemeinschaft (publication no. 151 of the Sonderforschungsbereich 313 at Kiel University). 


\section{LITERATURE CITED}

Aller, J. Y., Aller, R. C. (1986). Evidence for localized enhancement of biological activity associated with tube and burrow structures in deep-sea sediments at the HEBBLE site western North Atlantic. Deep Sea Res. 33: 755-790

Austin, B. (1988). Deep-sea bacteria. In: Austin, B. (ed.) Methods in aquatic bacteriology. John Wiley and Sons, New York, p. 193-204

Bender, M. L., Heggie, D. T. (1984). Fate of organic carbon reaching the deep sea floor: a status report. Geochim. cosmochim. Acta 48: 977-986

Billen, G. (1982). Modelling the processes of organic matter degradation and nutrient recycling in sedimentary systems. In: Nedwell, D. B., Brown, C. M. (eds.) Sediment microbiology. Academic Press, London, p. 15-52

Chastain, R. A., Yayanos, A. A. (1991). Ultrastructural changes in an obligately barophilic marine bacterium after decompression. Appl environ. Microbiol. 57: 1489-1497

Chrzanowski, T. H., Crotty, R. D., Hubbard, J. G., Welch, R. P. (1984). Applicability of the fluorescein diacetate method for detecting active bacteria in freshwater. Microb. Ecol, 10: $179-185$

Cole, J. J., Honjo, S., Erez, J. (1987). Benthic decomposition of organic matter at a deep-water site in the Panama Basin. Nature, Lond. 327: 703-704

Deming, J. W. (1985). Bacterial growth in deep-sea sediment trap and boxcore samples. Mar. Ecol. Prog. Ser. 25: 305-312

Deming, J. W. (1986), Ecological strategies of barophilic bacteria in the deep ocean. Microbiol. Sci. 3: 205-211

Deming, J. W., Baross, J. A. (1992). The early diagenesis of organic matter: bacterial activity. In: Engel, M., Macko, S. (eds.) Organic geochemistry. Plenum Press, New York (in press)

Deming, J. W., Colwell, R. R. (1985). Observations of barophilic microbial activity in samples of sediment and intercepted particulates from the Demerara Abyssal Plain. Appl. environ. Microbiol. 50: 1002-1006

Gooday, A. J. (1988). A response by benthic Foraminifera to the deposition of phytodetritus in the deep-sea. Nature, Lond 332: 70-73

Gooday, A. J., Lambshead, P. J. D. (1989). Influence of seasonally deposited phytodetritus on benthic foraminiferal populations in the bathyal northeast Atlantic: the species response. Mar. Ecol. Prog. Ser. 58: 53-67

Graf, G. (1989). Benthic-pelagic coupling in a deep-sea benthic community. Nature, Lond. 341: 437-439

Jannasch, H. W. (1979). Microbial turnover of organic matter in the deep sea. Biosci. 29: 228-232

King, G. M. (1986). Characterization of $\beta$-glucosidase activity in intertidal marine sediments. Appl. environ. Microbiol. 51. $373-380$

Kirchman, D. L., Murray, R. E., Hodson, R. E. (1986). Rates of DNA and protein synthesis by heterotrophic bacteria in aquatic environments: a comparison between the thy-

This article was submitted to the editor midine and leucine approaches. In: Megusar, F., Gantar, M. (eds.) Perspectives in microbial ecology. Slovene Society for Microbiology, Ljubljana, p. 631-637

Köster, M., Jensen, P., Meyer-Reil, L.-A. (1991a). Hydrolytic activity associated with organisms and biogenic structures in deep-sea sediments. In: Chrost, R. Y (ed.) Microbial enzymes in aquatic environments. Springer-Verlag, Berlin, p. $298-310$

Köster, M., Charfreitag, O., Meyer-Reil, L.-A. (1991b). Availability of nutrients to a deep-sea benthic microbial community: results from a ship-board experiment. Kieler Meeresforsch. (Sonderh.) 8: 127-138

Lochte, K., Turley, C. M. (1988). Bacteria and cyanobacteria associated with phytodetritus in the deep sea. Nature, Lond. 333: 67-69

Lundgren, B. (1981). Fluorescein diacetate as a stain of metabolically active bacteria in soil. Oikos $36: 17-22$

Mayer, L. M. (1989). Extracellular proteolytic enzyme activity in sediments of an intertidal mudflat. Limnol. Oceanogr. 34: $973-981$

Meyer-Reil, L.-A. (1984). Bacterial biomass and heterotrophic activity in sediments and overlying waters. In: Hobbie, J. E., Williams, P. J. leB. (eds.) Heterotrophic activity in the sea. Plenum Press, New York, p. 523-546

Meyer-Reil, L.-A. (1990). Microorganisms in marine sediments: considerations concerning activity measurements. Arch. Hydrobiol. (Beih. Ergebn. Limnol.) 34: 1-6

Meyer-Reil, L.-A. (1991). Ecological aspects of enzymatic activity in marine sediments. In: Chrost, R. J. (ed.) Microbial enzymes in aquatic environments. Springer-Verlag, Berlin, p. 84-95

Meyer-Reil, L.-A., Köster, M. (1991). Fine-scale distribution of hydrolytic activity associated with foraminiferans and bacteria in deep-sea sediments of the Norwegian-Greenland Sea. Kieler Meeresforsch. (Sonderh.) 8: 121-126

Morita, R. Y (1979). Current status of the microbiology of the deep-sea. Ambio (Spec. Rep.) 6: 33-36

Morita, R. Y (1982). Starvation-survival of heterotrophs in the marine environment. In: Marshall, K. C. (ed.) Advances in microbial ecology. Plenum Press, New York, p. 171-198

Reimers, C. E., Smith, K. L. Jr (1986). Reconciling measured and predicted fluxes of oxygen across the deep sea sediment-water interface. Limnol. Oceanogr. 31: 305-318

Rowe, G. T., Deming, J. W. (1985). The role of bacteria in the turnover of organic carbon in deep-sea sediments. J. mar Res. 43: 925-950

Schnürer, J., Rosswall, T (1982). Fluorescein diacetate hydrolysis as a measure of total microbial activity in soil and litter. Appl environ. Microbiol. 43: 1256-1261

Swisher, R., Carroll, G. C. (1980). Fluorescein diacetate hydrolysis as an estimator of microbial biomass on coniferous needle surfaces. Microb. Ecol. 6: 217-226

Turley, C. M., Lochte, K., Patterson, D. J. (1988). A barophilic flagellate isolated from $4500 \mathrm{~m}$ in the mid-North Atlantic Deep Sea Res. 35: 1079-1092

Manuscript first received: August 19, 1991

Revised version accepted: February 20, 1992 